\title{
Phytoplankton in Coqueiro Lake (Pantanal de Poconé, Mato Grosso, Brazil)
}

\author{
Sandra Francisca Marçal ${ }^{1 *}$ \\ Simoni Maria Loverde-Oliveira ${ }^{2}$ \\ ${ }^{1}$ Programa de Pós-Graduação em Ciências Ambientais, Universidade de Cuiabá \\ Avenida Beira Rio, 3100, CEP 78065-900, Cuiabá - MT, Brasil \\ ${ }^{2}$ Universidade Federal de Mato Grosso \\ Rodovia Rondonópolis-Guiratinga km 6, CEP 78735-901, Rondonópolis - MT, Brasil \\ * Autor para correspondência \\ sandraabio@gmail.com
}

Submetido em 04/09/2014

Aceito para publicação em 20/02/2015

\section{Resumo}

Fitoplâncton da baía do Coqueiro (Pantanal de Poconé, Mato Grosso). Estudos sobre a composição florística são essenciais para compreender mudanças quali-quantitativas nas assembleias fitoplanctônicas ao longo do ano. A variação espaço-temporal da composição, riqueza, frequência de ocorrência e abundância (semiquantitativa) da comunidade fitoplanctônica foi analisada mensalmente (de abril de 2002 a maio de 2003), em três estações, na baía do Coqueiro (Pantanal, Mato Grosso). Foram registrados 256 táxons, representados principalmente por Zygnematophyceae (36\%), Chlorophyceae (21\%) e Euglenophyceae (14\%). A maior abundância média ocorreu na estação limnética (2), porém, Bacillariophyceae, Cyanophyceae, Chlorophyceae e Zygnematophyceae prevaleceram nas três estações. A maior riqueza média foi obtida na estação litorânea (3), porém, essa estação apresentou abundância significativamente menor $(\mathrm{p}<0,05)$ que as duas estações limnéticas. $O$ sistema caracterizou-se por maiores contribuições de Chlorophyceae no período de vazante, Bacillariophyceae na estiagem, Cyanophyceae na enchente e Zygnematophyceae na cheia, e, em média, a maior riqueza e abundância foram registradas na estiagem (Aulacoseira spp., Coelastrum spp., Anabaena spp., Aphanocapsa minutissima, Planktolyngbya spp. e Eutetramorus fottii). Os atributos da comunidade fitoplanctônica apresentaram variações espaciais e temporais, influenciadas pela presença de macrófitas, mas definidas, sobretudo, pelas mudanças hidrológicas sazonais, causadas pelo pulso de inundação.

Palavras-chave: Biodiversidade; Composição florística; Lagoas rasas

\section{Abstract}

Studies on floristic composition are key to understand qualiquantitative changes on phytoplankton assemblages over the year. Spatial-temporal variation in composition, richness, frequency of occurrence, and abundance (semi-quantitative) of the phytoplankton community was analyzed monthly (from April 2002 to May 2003), at 3 stations, in Coqueiro Lake (Pantanal, Mato Grosso, Brazil). We registered 256 taxa, mainly represented by Zygnematophyceae (36\%), Chlorophyceae (21\%), and Euglenophyceae (14\%). The highest average abundance occurred at the limnetic station (2), but Bacillariophyceae, Cyanophyceae, Chlorophyceae, and Zygnematophyceae prevailed at the 3 stations. The highest average richness was obtained at the littoral station (3), but this station showed a significantly lower abundance $(\mathrm{p}<0.05)$ than the 2 limnetic stations. The system 
was characterized for higher contributions of Chlorophyceae in the falling water period, Bacillariophyceae in the low waters, Cyanophyceae in the rising waters and Zygnematophyceae in the high waters, and, on average, the highest richness and abundance were registered in the drought (Aulacoseira spp., Coelastrum spp., Anabaena spp., Aphanocapsa minutissima, Planktolyngbya spp. and Eutetramorus fottii). The attributes of phytoplankton community showed spatial and temporal variations, influenced by the presence of macrophytes, but defined, above all, by seasonal hydrologic changes, caused by the flooding pulse.

Key words: Biodiversity; Floristic composition; Shallow lakes

\section{Introduction}

In environments subject to seasonal floods, oscillations in water level are regarded as the driving force in plankton community dynamics (HUSZAR; REYNOLDS, 1997; HUSZAR et al., 1998; TRAIN; RODRIGUES, 1998; CARDOSO et al., 2012), where a set of synergistic environmental and spatial factors respond to these hydrologic variations and lead to changes in communities (LOVERDE-OLIVEIRA et al., 2012). Thus, phytoplankton population cycles are constantly changing, and this causes qualitative and quantitative responses by assemblages over the year (REYNOLDS, 1984). Therefore, knowing the floristic composition of a phytoplankton community is key to understand variations in biomass and density, describe functional groups, trophic status, and dynamics of an aquatic ecosystem (HUSZAR et al., 1998; NABOUT; NOGUEIRA, 2007).

Studies about algal communities in tropical regions are scarce and incipient (LOVERDE-OLIVEIRA et al., 2012), but it has been shown that quantitative and qualitative variations are related to the climatic and hydrologic regime (PAYNE, 1986; DIAS JR., 1990; ESPÍNDOLA et al., 1996; LOVERDE-OLIVEIRA; HUSZAR, 2007), and that phytoplankton dynamics is controlled by a combination of several hydrodynamic processes acting on different spatial and temporal scales (CALIJURI, 1988).

In Brazil, a few research groups on phytoplankton have been consolidated this decade (BICUDO; MENEZES, 2010; NASCIMENTO, 2010; LOVERDEOLIVEIRA et al., 2011); in the state of Mato Grosso, studies on phytoplankton are focused on the Pantanal (JUNK et al., 2006; LOVERDE-OLIVEIRA et al., 2012) and they follow an ecological descriptive trend
(TREMARIN et al., 2011). These studies are almost always related to the hydrologic flooding pulse (JUNK et al., 1989) and they use relative abundance (HECKMAN et al., 1993; DE-LAMONICA-FREIRE; HECKMAN, 1996; LIMA, 1996; MARÇAL, 2005), density and biomass (LOVERDE-OLIVEIRA, 2005; LOVERDEOLIVEIRA; HUSZAR, 2007; CARDOSO et al., 2012; LOVERDE-OLIVEIRA et al., 2012), and primary productivity (BAMBI et al., 2008) to describe the communities. In all those studies, the composition and richness of phytoplankton species were considered. This is a major element regarding knowledge on biodiversity, used in applied studies (e.g. LOVERDE-OLIVEIRA et al., 2009) and floristic comparisons between different ecosystems (HUSZAR, 1996; LOVERDE-OLIVEIRA et al., 2011).

Along with floristic knowledge, there is a growing need to investigate phytoplankton ecology in the Pantanal (LOVERDE-OLIVEIRA et al., 2012), since this is a peculiar, wide, and complex system (BOZELLI; HUSZAR, 2003). Knowledge on qualitative and quantitative composition and phytoplankton productivity is crucial for better using these ecosystems (DIAS JR., 1990), as studying plankton organisms from marginal lakes may provide primordial information to develop ecological theories.

It is worth emphasizing that the current knowledge on epicontinental algae, with higher concentration of studies in the Brazilian South and Southeast regions and lower concentration in the North and CentralWest regions (BICUDO; MENEZES, 2010), is very heterogeneous, not only when the geographic region is taken into account, but also when the taxonomic group is considered. Therefore, studies based on ecological compositional and diversity attributes are needed to boost applied and experimental research on 
phytoplankton. Thus, this study aimed to analyze the composition, species richness, frequency of occurrence, and abundance (semi-quantitative) of phytoplankton species at three sampling stations in Coqueiro Lake, at the different phases of the hydrological cycle in the Pantanal.

\section{Material and Methods}

\section{Study area}

Coqueiro Lake (Figure 1) is located in the municipality of Nossa Senhora do Livramento (16 $6^{\circ} 15^{\prime} 12$ 'S; $56^{\circ} 22$ '12”W), within the sub-region Pantanal de Poconé, in the state of Mato Grosso, Brazil. It is a floodplain permanent lake, with elongated shape, $4 \mathrm{~km}$ long and $1 \mathrm{~km}$ wide (total area: $<2.5 \mathrm{~km}^{2}$ ); it is shallow (maximum depth: $2.3 \mathrm{~m}$ ) (LOVERDEOLIVEIRA et al., 2007). During the drought, this lake remains isolated from the other water bodies and during the flood it is connected to Piraim river, a tributary on the right bank of Cuiabá river. The region climate (Köppen) is Aw type, warm and wet, with rainfalls in summer and low water in winter. Total annual rainfall $(1,259$ $\mathrm{mm})$ and the annual average air temperature $\left(27^{\circ} \mathrm{C}\right)$ are within the climatological patterns within the region, when compared to the historical means $(800-1,600 \mathrm{~mm}$ and $26^{\circ} \mathrm{C}$, respectively) (LOVERDE-OLIVEIRA et al., 2007).

\section{Sampling and data analysis}

Data on rainfall in the region was provided by the $9^{\text {th }}$ Weather Forecast District of the National Institute of Meteorology (INMET), Cuiabá, Mato Grosso, Brazil.

Phytoplankton samples $(\mathrm{n}=39)$ were taken monthly, from April 2002 to May 2003 using plankton net $(25 \mu \mathrm{m})$ and they were preserved with Transeau (1:1). Samplings were accomplished through 10 vertical hauling on the water column at three sampling stations: site 1- on the limnetic region under lotic influence during the flood; site 2-on the deepest part from the limnetic region in the lake; and site 3- located on the littoral region close to aquatic macrophytes (Eichhornia azurea (SW.) Kunth, E. crassipes (Mart) Solms-Laubach, Salvinia sp. Weevil).

In order to determine the abundance and frequency of occurrence, samples were previously homogenized, and we used $0.5 \mathrm{~mL}$ by glass slide. The number of slides was previously determined through the curve speciesarea, totaling 15 slides/sample. Thus, the phytoplankton community was characterized qualitatively and semi-

FIGURE 1: Location of Coqueiro Lake within Pantanal de Poconé and the samplings sites.

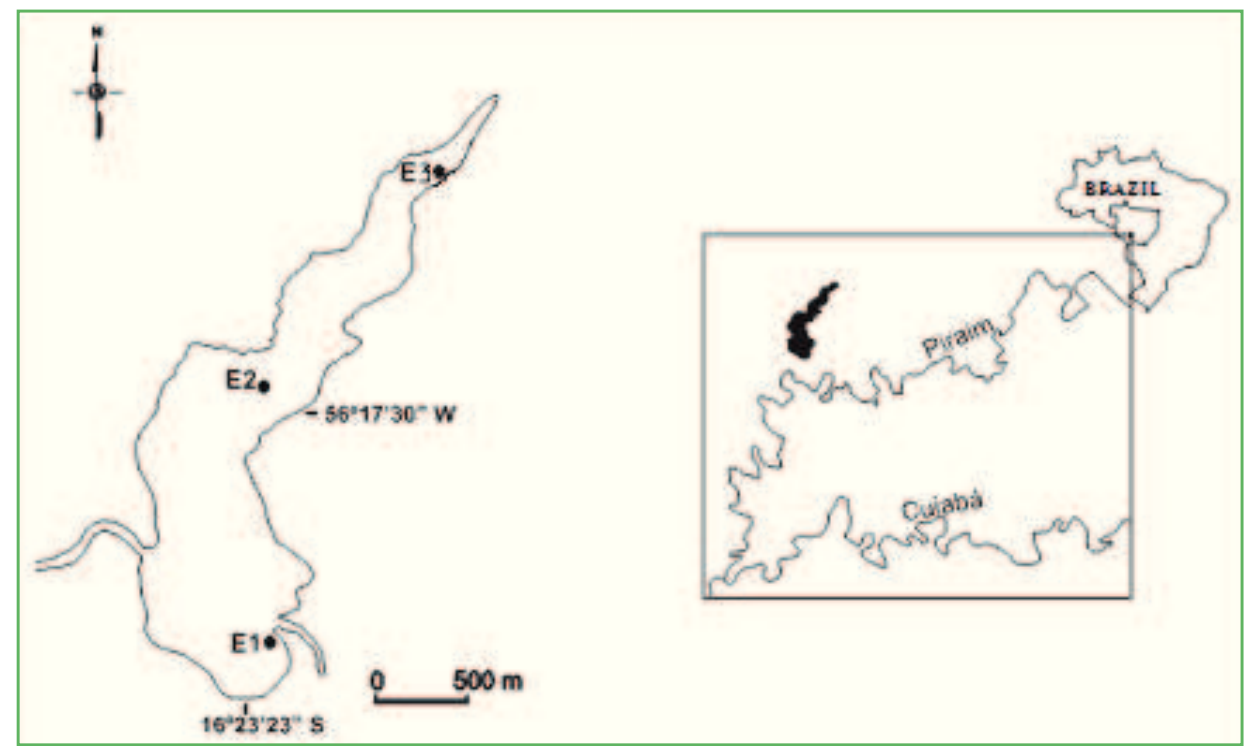

Source: Loverde-Oliveira (2005). 
quantitatively by counting of taxa and importance (numerical abundance) of each taxon in the samples, respectively.

For the qualitative analysis, the material was oxidized, according to Simonsen (1979), modified by Moreira-Filho and Valente-Moreira (1981). We adopted the classification system provided by Van den Hoek et al. (1997).

The species were regarded as abundant and dominant according to the criteria provided by Lobo and Leighton (1986). The frequency of occurrence (F) was expressed as the relationship between the occurrence of different species and the total number of samples. The species were classified as constant when $\mathrm{F}>60 \%$; common: $20 \%<\mathrm{F}$ $<60 \%$; and rare: $\mathrm{F}<20 \%$ (GOMES, 1989).

Based on the results of rainfall and water level, 4 periods were established: period I-falling or decrease in water level (April to July 2002); period II-low water (August to November 2003); period III-rising or increase in water level (December 2002 and January 2003); and period IV-high water (February to May 2003).

Through the numerical abundance within seasonal periods and at the sampling stations, we conducted a Cluster Analysis (Systat 12) and a Friedman Analysis of Variance $(\alpha=0.05$; BioEstat 5.0).

\section{Results}

\section{Variations in rainfall and water level}

The lower rainfall values within the Cuiabá region occurred during the falling (period I) and the higher ones, from October, with a maximum $(297 \mathrm{~mm})$ in January 2003, within period III. At this time, there was a flood in the Cuiabá river floodplain, with a consequent increase in water level in Coqueiro Lake. The period of high water (IV) was characterized by decrease in rainfall and higher values in average depth on the water column (Figure 2).

\section{Community attributes}

\section{Species composition}

In the phytoplankton community of Coqueiro Lake, 256 taxa were identified, distributed into 10 taxonomic classes: Zygnematophyceae (92), Chlorophyceae (58), Euglenophyceae (35), Cyanophyceae ( 33 ), B a cillariophyce a (25), Xantophyceae (6), Chrysophyceae (3), Dinophyceae (1), Oedogoniophyceae (2) and Cryptophyceae (1) (Figure 3; Appendix 1 and 2).

FIGURE 2: Variation in rainfall and mean depth in Coqueiro Lake from April 2002 to May 2003. (Periods: I-falling; II-low water; IIIrising; IV-high water and beginning of the falling).

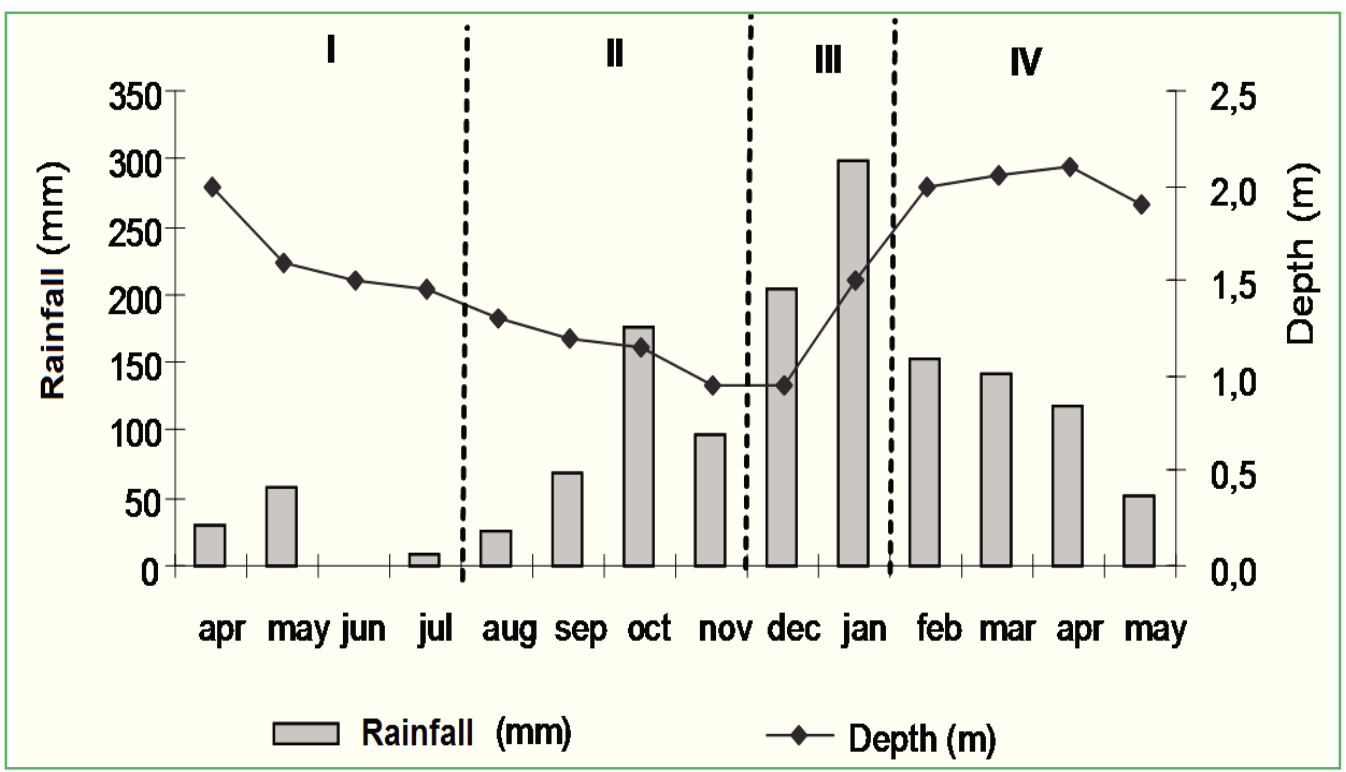


FIGURE 3: Relative contribution of taxonomic classes to the phytoplankton from Coqueiro Lake.

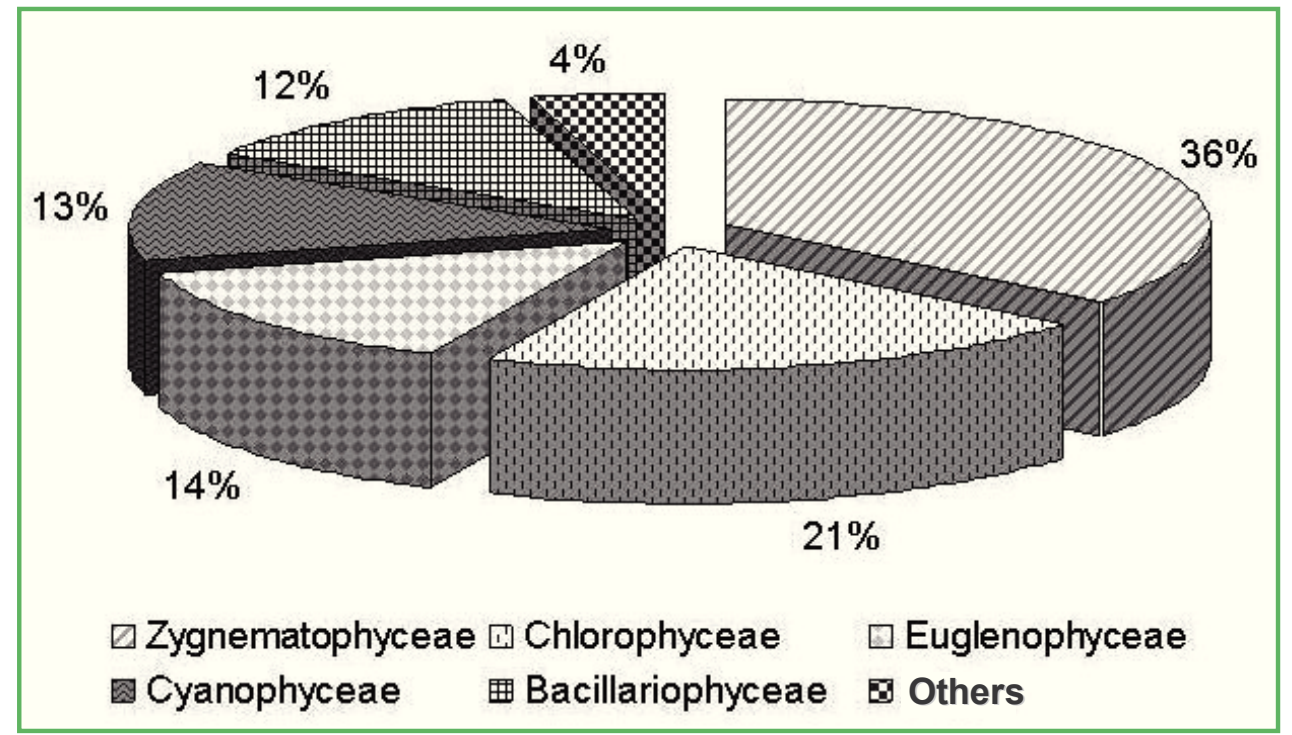

\section{Richness, abundance and dominance}

Species richness in the limnetic site (1) ranged from 37-113 taxa sample ${ }^{-1}$; at the other limnetic site (2) this attribute had values between 27-110 taxa sample ${ }^{-1}$; and the littoral site (3) was characterized by the highest average of species richness, varying between 58-159 taxa sample ${ }^{-1}$ (Table 1; Figure 4).

Considering temporal variation in species richness, within period II, the highest average of species richness was registered ( $87 \pm 29$ taxa sample $\left.{ }^{-1}\right)$ with the emergence of Chlorophyceae [Kirchneriella contorta Schmidle, Scenedesmus acuminatus (Lagerh.) Chodat] (Table1; Figure 4; Appendix 2). Within periods I, III, and IV, we observed the highest contribution of periphytic algae for the species richness, mainly the [Hyalotheca dubia (Kutzing)] (period I),
Spirogyra sp., Mougeotia sp., Hyalotheca dissiliens (Smith) Brébisson, Closterium setaceum (Ehrenberg) Ralfs and Nitzschia sp. mainly in the littoral site (period III) and Zygnematophyceae as [Gonatozygon monotaenium (De Bary), Teilingia wallichi (Jacobsen) Bourrelly var. anglica (W. and West) Foster] (period IV) (Table 1; Figure 4; Appendix 2).

Abundance at the limnetic site (1) varied between 125-8007 ind.sample ${ }^{-1}$; at the limnetic site 2 , it ranged from 63-13114 ind.sample ${ }^{-1}$, thus it had the highest mean value $\left(3712 \pm 5157\right.$ ind.sample $\left.{ }^{-1}\right)$, and at the littoral site (3) we found the variation of 347-9858 ind. sample $^{-1}$, representing the lowest average abundance by site $\left(2538 \pm 2742\right.$ ind.sample $\left.{ }^{-1}\right)$ (Table 1; Figure 4). Phytoplankton abundance was similar between the limnetic sites $(p=0.4769)$ and significantly different when compared to the littoral site $(p<0.05)$.

TABLE 1: Mean variation and standard deviation of species richness and numerical abundance for the periods I, II, III, and IV and sampling sites E1, E2 and E3 in Coqueiro Lake.

\begin{tabular}{|c|c|c|c|c|c|c|c|}
\hline \multirow{2}{*}{ Variables } & \multicolumn{4}{|c|}{ Periods } & \multicolumn{3}{|c|}{ Sites } \\
\hline & I & II & III & IV & 1 & 2 & 3 \\
\hline $\begin{array}{c}\text { Richness } \\
\text { (taxa/sample) }\end{array}$ & $71 \pm 23$ & $87 \pm 29$ & $64 \pm 30$ & $67 \pm 32$ & $69 \pm 22$ & $55 \pm 24$ & $96 \pm 25$ \\
\hline $\begin{array}{c}\text { Abundance } \\
\text { (ind. sample } \text { s. }^{-1} \text { ) }\end{array}$ & $1197 \pm 1243$ & $6930 \pm 3728$ & $3990 \pm 3585$ & $376 \pm 307$ & $2850 \pm 2673$ & $3712 \pm 5157$ & $2538 \pm 2742$ \\
\hline
\end{tabular}


FIGURE 4: Variation in numerical abundance and taxa richness at sites E1, E2, and E3; periods: I- falling; II- low water; III- rising; IVhigh water and beginning of the falling.

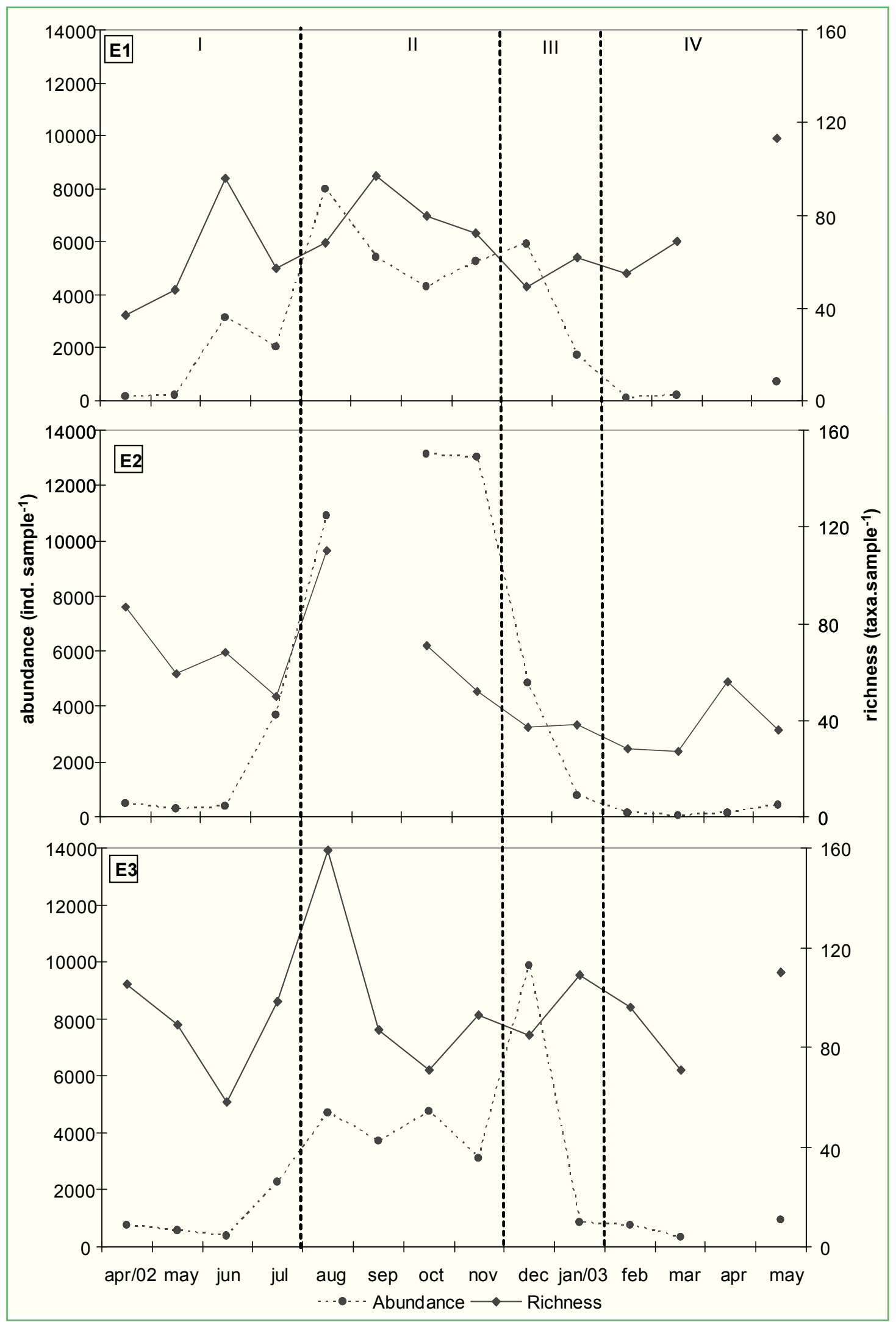


Abundance within periods I and II was significantly different from that registered within periods III $(\mathrm{p}<0.0161$ and $\mathrm{p}<0.0001)$ and IV $(\mathrm{p}<0.0001$ and $\mathrm{p}<0.0249)$. The highest contributions to abundance were registered within periods II $\left(6930 \pm 3728\right.$ ind.sample $\left.{ }^{-1}\right)$ with occurrence of Bacillariophyceae [Aulacoseira granulata Ehrenberg (Simonsen) var. granulata, Aulacoseira ambigua (Grunow) Krammer, Aulacoseira granulata Ehrenberg (Simonsen) var. angustissima] and Cyanophyceae [Planktolyngbya circuncreta (G. S. West) Anagnostides and Komárek, Anabaena planctonica Brunnthaler, Aphanocapsa minutissima (W. \& W.) Kom.-Leg. \& Cronb., Planktolyngbya sp.], along with Chlorophyceae [Coelastrum pulchrum Shimidle, Coelastrum reticulatum (Dangeard) Senn, Eutretramorus fottii Hindak]. Within period III (1197 \pm 1243 ind.sample $\left.{ }^{-1}\right)$, we observed a predominance of Cyanophyceae [P. circuncreta, Planktolyngbya sp., A. minutissima], Bacillariophyceae [A. granulata var. granulata, A. granulata var. angustissima] and Chlorophyceae [Coelastrum indicum Turner, E. fottii, C. reticulatum] (Table 1; Figure 5; Appendix 2).

FIGURE 5: Relative abundance of taxonomic classes at the sites E1, E2, and E3; periods: I-falling; II-low water; III-rising; IV-high water and beginning of the falling.

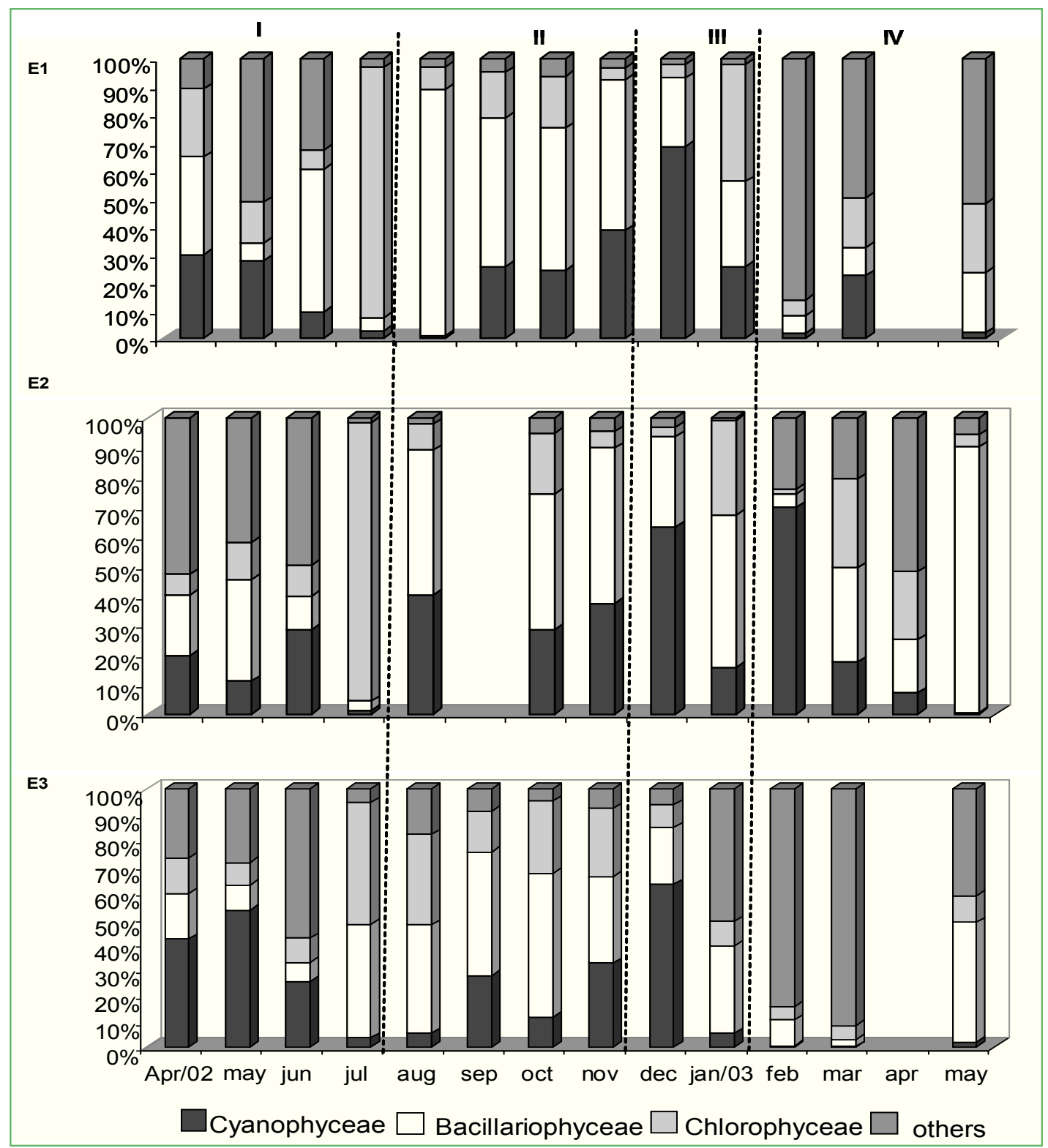


Within period I, we registered an expressive occurrence of Chlorophyceae [C. reticulatum], Bacillariophyceae [A. ambigua, A. granulata var. granulata, Aulacoseira italica Ehrenberg (Simonsen), Surirella robusta Ehrenberg], Zygnematophyceae [H. dubia and Staurastrum leptocladum Nordstedt] and Cyanophyceae [Oscillatoria tenuis C. Agardh (Gomont), Oscillatoria sancta Kutzing (Gomont), Oscillatoriales 1]. In the period IV, the expressive occurrence of Zygnematophyceae [H. dissiliens], Bacillariophyceae [A. ambigua, Fragillaria sp., Surirella sp4.], Euglenophyceae [Trachelomonas cf. volvocinopsis Swirenko] and Chlorophyceae [E. fottii] was registered (Figure 5; Table 1).

There was higher similarity in the variation of phytoplankton abundance between the sites E1 and E2, and $\mathrm{E} 3$ was the most distinct in comparison to the other two. Between the periods from the hydrological cycle, periods I and IV were more similar, as well as periods II and III (Figure 6). Concerning spatial variation in species classified as abundant and dominant, we observed maximum values of $A$. granulata var. granulata in August 2002 (50\%) and September 2002 (79\%), both at the limnetic site (1) and that of Chlorophyceae C. reticulatum (87\%) in July 2002 also at the site (1) (Appendix 2). In July 2002, C. reticulatum also contributed with $92 \%$ to abundance at the limnetic site (2) and Aphanothece smithii Komárková-Legnerová $\&$ Cronberg., represented $68 \%$ from the total of the community abundance in February 2003, at this site. In relation to the littoral site, there was no abundant and dominant species, but A. ambigua contributed with around $40 \%$ to abundance in October 2002, and Lepocinclis ovum (Ehrenberg) Lemmermann, A. ambigua and $E$. fottii were constant throughout the seasonal cycle at this site (Figure 5). Furthermore, we registered species constancy and dominance of Aulacoseira spp. throughout the hydrological cycle.

\section{Frequency of occurrence}

When considering the frequency of occurrence, at the first limnetic site, $58 \%$ of the species were considered as rare, $34 \%$ as common, and $8 \%$ as constant. At the site (2), $69 \%$ of the species were classified as rare, $27 \%$ as common and $4 \%$ as constant. The littoral site (3) consisted in $42 \%$ of rare species, $48 \%$ common, and 10\% constant (Figure 7).

Out of the total number of species identified (256 taxa), 111 were rare, 45 were common, and 7 species were registered as constant for the 3 sites. Most of the rare species belong to the Zygnematophyceae class, such as

FIGURE 6: Dendrograms of Sorensen similarity for numerical abundance among the sites (E1, E2, and E3) and between the periods (PI, PII, PIII, and PIV).

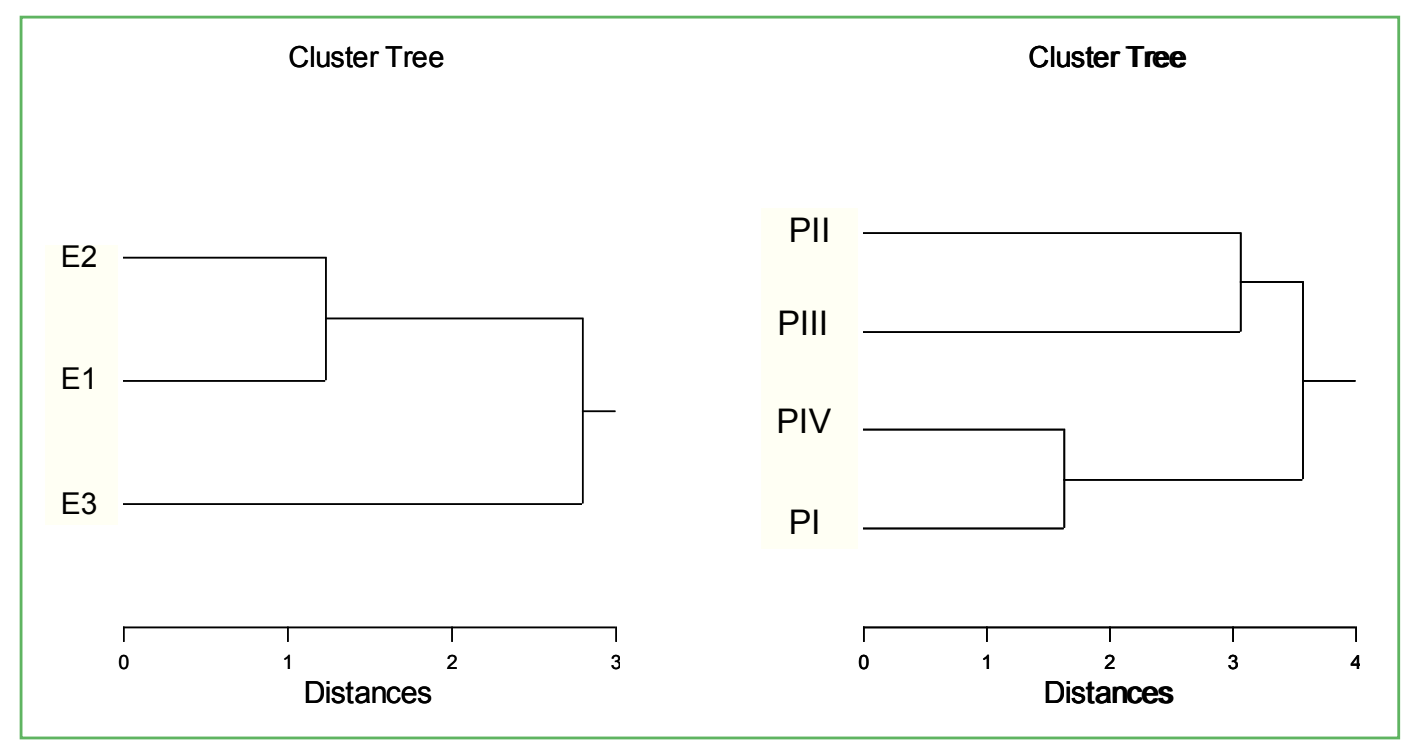


FIGURE 7: Frequency of occurrence of species rare, common and constant, at the 3 sites from April 2002 to May 2003.

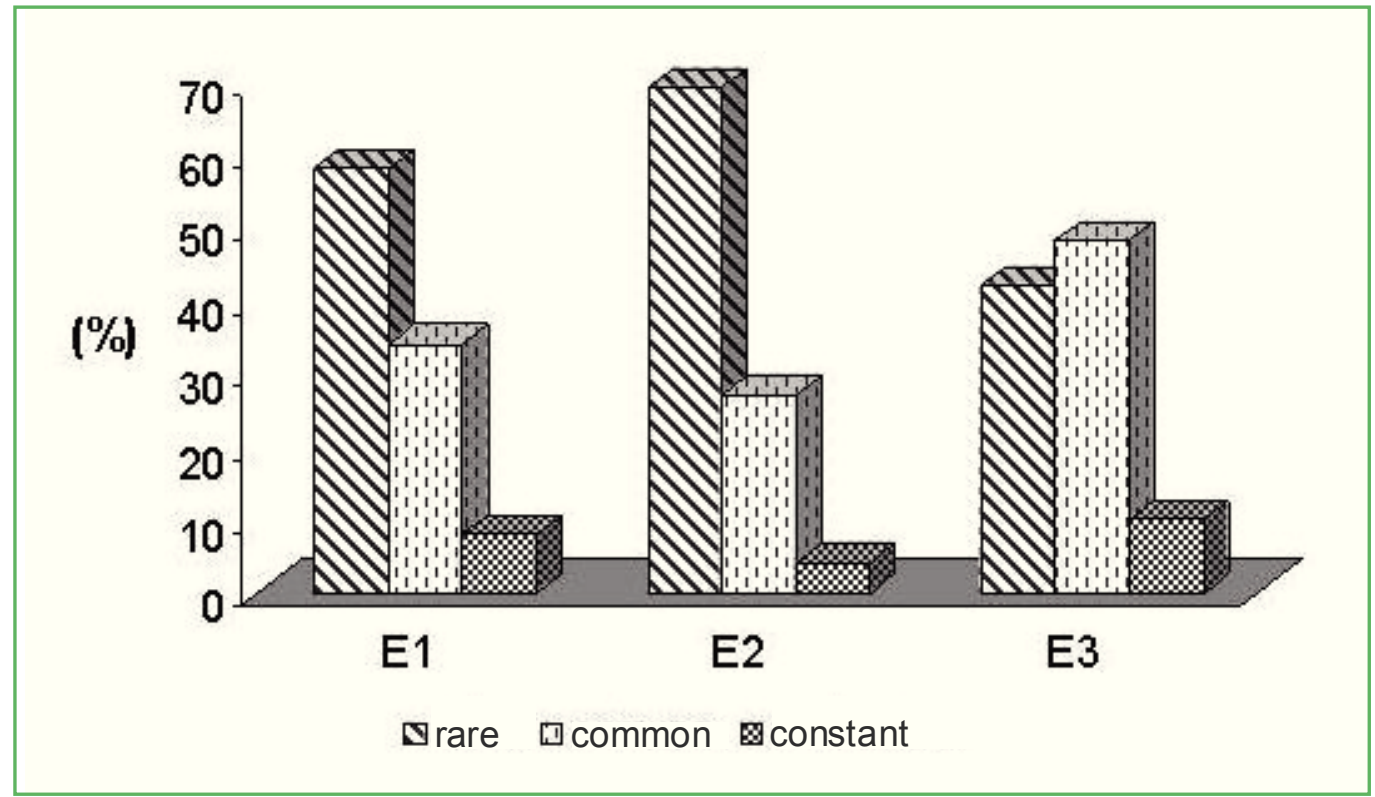

Closterium acutum (Brébisson) Ralfs, G. monotaenium, Cosmarium lagoense (Nordstedt) Nordstedt; regarding the common species, the highest number belongs to the classes Cyanophyceae [A. planctonica] and Chlorophyceae [K. contorta, Crucigeniella crucifera (Wolle) Komárek, Oocystis lacustris (Chodat) and Pandorina morum (Muller) De Bary]. The following Cyanophyceae species were constant at all sites: P. circuncreta, and Planktolyngbia sp.; as well as Bacillariophyceae species [A. ambigua, A. granulata var. granulata] and Chlorophyceae species [C. reticulatum and E. fottii] (Appendix 2).

\section{Discussion}

Coqueiro Lake has a floristic composition similar to the other aquatic systems in the Pantanal, but different from the other rising lakes (LIMA, 1996; DELAMONICA-FREIRE; HECKMAN, 1996), due to the high values of species richness and abundance.

Zygnematophyceae was relevant due to the higher number of species mainly within the rising period, as evidenced for floodplain lakes in the Pantanal under the influence of Paraguay river (DE-LAMONICA-FREIRE; HECKMAN, 1996), Mogi-Guaçu river (DIAS JR., 1990), floodplain lakes in the Amazon region (HUSZAR et al., 1998) and middle Paraná river, where this class presents selective advantage in more protected systems with low flow (RODRIGUES et al., 2001; 2002). The higher contribution of the Chlorophyceae class for species richness is widely evidenced in the floodplains of Paraná river (TRAIN; RODRIGUES, 1998; TRAIN et al., 2001; RODRIGUES et al., 2002; ZALOCAR DE DOMITROVIC, 2003), Paraguay river (OLIVEIRA; CALHEIROS, 2000; SILVA et al., 2000; ZALOCAR DE DOMITROVIC, 2002) and Cuiabá river in the Pantanal (LIMA, 1996; LOVERDE-OLIVEIRA, 2005).

Great contributions by Zygnematophyceae, in the high water period, are related to the high number of representatives from the periphytic community [Gonatozygon monotaenium, Hyalotheca dissiliens, Bambusina borreri, Staurodesmus clepsydra Teiling and Teilingia wallichi], also described by Camargo et al. (2009). The occurrence of these species on plankton may be related to water turbulence, which causes the detachment of these organisms from the substrate, contributing to the increased species richness on phytoplankton. According to Train (1998), interrelations between phytoplankton and periphyton, with several species regularly occurring in both biotopes, are frequently observed in shallow lakes colonized by aquatic macrophytes. 
The great contribution by Chlorophyceae to species richness, after the rising period, may have occurred due to the higher availability of light on the water column, since Coqueiro Lake, during the high water in the hydrological cycle, has a deep euphotic zone (LOVERDE-OLIVEIRA, 2005). Euglenophyceae were benefited by the increased availability of organic matter within the rising period, where there is a great input of allochthonous material in the lakes of Pantanal, coming from adjacent lotic systems (NOGUEIRA, 1989) and the floodplain. The higher contribution by Euglenophyceae was registered under conditions of low hydrometrical level and reduced water transparency (RODRIGUES et al., 2002). In the Paraguay river and Tamengo Channel in the Pantanal of Mato Grosso do Sul, a greater species richness of this group was observed during the rising, with contributions by Trachelomonas volvocina Ehernberg and Trachelomonas volvocinopsis (SILVA et al., 2000).

Greater richness in the dry season and lowest richness in the rising and high water also have been reported by Loverde-Oliveira (2005) and LoverdeOliveira and Figueiredo (2009). The greater abundance in floodplain lakes during the low water are due to the reduced depths and wind action that, among other factors, are determinant of conditions involving high turbulence, turbidity, and high availability of nutrients (LOVERDE-OLIVEIRA, 1999; TRAIN et al., 2001). The flood is responsible for decreased phytoplankton abundance, primarily due to the dilution effect, which determines a decrease in planktonic populations (LOVERDE-OLIVEIRA; HUSZAR, 2007), along with a increase in the number of taxa and diversity (TRAIN et al., 2001).

Abundance was represented by few species (Aulacoseira spp., Coelastrum reticulatum, Planktolyngbya sp., Anabaena spp. and Eutetramorus fottii). This finding was expected, because the communities consist of a small number of species with many individuals or, sometimes, by only one species that prevails along with several species with lower representativeness (MARGALEF, 1983). The temporal distribution pattern shown by abundance accompanies the hydrometric fluctuation generated by the flood pulse, with periods in the hydrological cycle significantly different, whose maximum lies on the low waters and the minimum on the high waters.

Among the centric diatoms registered in the Coqueiro Lake, Aulacoseira granulata has shown high abundance values regardless of the period in the seasonal cycle, however, the conditions found in the low water are key for the establishment and reproductive success of these algae (REYNOLDS, 1984), as they are characterized by dominance in environments with constant movements in the water column, facilitating permanence in the euphotic zone, besides nutrient availability (MOURA, 1997). The dominance of Aulacoseira granulata and its varieties were registered in Sá Mariana Lake (LOVERDE-OLIVEIRA, 1999) and Recreio (LIMA, 1996), in the Pantanal; Patos Lake, in the Upper Paraná river floodplain (RODRIGUES et al., 2002), and also in Paraguay river (SILVA et al., 2000).

The high abundance among Cyanophyceae populations, including along with blooms, has been evidenced at the phases of the hydrological cycle when the shallow lakes in Paraná and the Pantanal showed lower depth (LIMA, 1996; LOVERDE-OLIVEIRA, 1999; TRAIN et al., 2001; RODRIGUES et al., 2002; LOVERDE-OLIVEIRA; HUSZAR, 2007). Increased concentrations of Anabaena spp. coincides with lower hydrometric levels, turbid water, and high water temperature and nutrient availability (HUSZAR et al., 1998; LOVERDE-OLIVEIRA, 2005, LOVERDEOLIVEIRA et al., 2009).

The higher influence of a river at the limnetic sites may explain the lower species richness on phytoplankton when compared to the littoral site with lower current flow and close to aquatic macrophyte stands. The greater number of rare species may have occurred due to the connectivity with to lotic systems that increase the flow of individuals coming from other niches. The inflow of the river to the marginal lakes causes changes in the physical and chemical characteristics of the water in the lakes, and thus changing the distribution, the composition and abundance of phytoplankton (DIAS JR., 1990).

The greater number of common species and species richness, mainly consisting in Zygnematophyceae and 
Euglenophyceae, were registered at the littoral site and this finding is associated with closeness to aquatic macrophytes that provide a constant supply of species detached from the periphyton and occurring on plankton, as the floristic composition of plankton from lentic and shallow biotopes, with or without connection to rivers or secondary channels, has phytoplankton complexity and similarity between diversity in the littoral and limnetic zones. The similarity between some biotopes with higher species richness in the littoral zone, when compared to the limnetic zone, is due to addition to the plankton of metaphytic and periphytic algae, mainly desmidiales and diatom (TRAIN et al., 2001). Thus, corroborating Loverde-Oliveira et al. (2012), the composition of phytoplankton community in marginal lagoons has a strong relation to habitat quality and it reflects the availability of niches in the aquatic ecosystem.

In general, the flood pulse was key to the variation in phytoplankton abundance in the Coqueiro Lake. The frequency of occurrence of rare, constant, and common species is also associated with oscillations in water level, corroborating the information that, in shallow lakes, seasonal variations in structure and abundance of plankton communities are generally combined to hydrometrical changes (LIMA, 1996).

The groups of phytoplankton algae had their abundance influenced by the hydrological cycle, with decrease during the high water and increase during the low water, probably responding to factors such as lotic influence, close to stands of aquatic macrophytes, among other physical and chemical factors of water. Variations in abundance, species richness, and frequency of occurrence evidenced that the dynamics of this community tends to be similar to other rising lakes driven by the flood pulse, but they keep peculiar characteristics of each aquatic system.

Based on our results, it was possible to verify a high richness of species of phytoplankton algae in the Coqueiro Lake. The composition and number of phytoplankton species in the lagoon proved to be influenced by closeness of macrophytes, promoting a interrelationships between phytoplankton and periphyton, and also by increased hydrological stability within the drought period. Just as underlined by the literature, the limnetic region shows a higher abundance of phytoplankton algae. The number of individuals (numerical abundance) was directly related to seasonal hydrological variations of the system, with its apex within the dry period, reasserting the flood pulse as the defining factor of the temporal and spatial distribution of richness and abundance.

Some authors (ALHO, 2011; ALHO, et al., 2011) have confirmed the importance of the increasing number of studies addressing floristic composition and spatialtemporal variations, which are key to improve knowledge on biodiversity in the Pantanal, a system requiring further investigation, as it has been increasingly threatened by anthropogenic pressures.

\section{Acknowledgements}

The authors would like to thank Vangil Pinto da Silva (in memoriam) and Flávia Maria Barros Nogueira for the scholarship; professor Albano Geraldo Emílio Magrin, for the manuscript review; Susicley Jati, from the Center for Research in Limnology, Ichthyology, and Aquaculture of the State University of Maringá (NUPELIA/UEM); and Maria da Graça Sophia, from the National Museum of the Federal University of Rio de Janeiro (UFRJ), for her collaboration in species identification. The authors also thank NEPA/UFMT, the National Council for Scientific and Technological Development (CNPq), and the Foundation for Research Support of the State of Mato Grosso (FAPEMAT) for the financial support.

\section{References}

ALHO, C. J. R. Concluding remarks: overall impacts on biodiversity and future perspectives for conservation in the Pantanal biome. Brazilian Journal of Biology, São Carlos, v. 71, n. 1, p. 337-341, 2011.

ALHO, C. J. R.; MAMEDE, S.; BITENCOURT, K.; BENITES, M. Introduced species in the Pantanal: implications for conservation. Brazilian Journal of Biology, São Carlos, v. 71, 1, p. 321-325, 2011. BAMBI, P.; DIAS, C. A. A.; PINTO-SILVA, V. Produção primária do fitoplâncton e as suas relações com as principais variáveis limnológicas na Baía das Pedras, Pirizal Nossa Senhora do Livramento, Pantanal de Poconé - MT. Revista Uniciências, Cuiabá, v. 12, n. 1, p. 47-68, 2008. 
BICUDO, C. E. M.; MENEZES, M. Introdução: as algas do Brasil. In: FORZZA, R. C. et al. (Ed.). Catálogo de plantas e fungos do Brasil. Vol.1. Rio de Janeiro: Andrea Jakobsson Estúdio: Instituto de Pesquisa Jardim Botânico do Rio de Janeiro, 2010. p. 49-60.

BOZELLI, R. L.; HUSZAR, V. L. M. Comunidades fito e zooplanctônicas em tempo de avaliação. Limnotemas, Rio de Janeiro, v. 3, n. 1, p. 1-15, 2003.

CALIJURI, M. C. Respostas fisioecológicas da comunidade fitoplanctônica e fatores ecológicos em ecossistemas com diferentes estágios de eutrofização. 1998. 293 f. Tese (Doutorado em Hidráulica e Saneamento) - Universidade de São Carlos, São Carlos. 1988.

CAMARGO, J. C.; LOVERDE-OLIVEIRA, S. M.; SHOPHIA, M. G.; NOGUEIRA, F. M. B. Desmídias perifíticas da baía do Coqueiro, Pantanal Matogrossense - Brasil. Iheringia, Porto Alegre, v. 64, n. 2, p. 25-41, 2009.

CARDOSO, S. J.; ROLAND F.; LOVERDE-OLIVEIRA, S. M.; HUSZAR, V. L. M. Phytoplankton abundance, biomass and diversity within and between Pantanal wetland habitats. Limnologica, Jena, v. 42, n. 3, p. 235-241, 2012.

DE-LAMONICA-FREIRE, E. M.; HECKMAN, C. W. The seasonal succession of biotic communities in wetlands of the tropical wetand-dry climat zone: III. The algal comminities in the Pantanal of Mato Grosso, Brazil, with a comprehensive list of the known species and revision of three desmid taxa. Internationale Revue der Gesamten Hydrobiologie und Hydrographie, Weinheim, v. 81, n. 2, p. 255-282, 1996.

DIAS JR., C. Ciclo anual do fitoplâncton e algumas variáveis ambientais na Lagoa do Infernão (SP). 1990. 108 f. Dissertação (Mestrado em Ecologia) - Universidade Federal de São Carlos, São Carlos. 1990.

ESPÍNDOLA, E. G.; MATSUMURA-TUNDISI, T.; MORENO, I. H. Estrutura da comunidade fitoplanctônica da lagoa Albuquerque (Pantanal Mato-Grossense), Mato Grosso do Sul, Brasil. Acta Limnologica Brasiliensia, Botucatu, v. 8, n. 1, p. 13-27, 1996.

GOMES, A. S. Distribuição espacial de moluscos bivalves na região da plataforma continental de Cabo Frio, (Praia de Maçambaba, estado do Rio de Janeiro, Brasil). 1989. $122 \mathrm{f}$. Dissertação (Mestrado em Ciências Biológicas) - Museu Nacional do Rio de Janeiro, Universidade Federal do Rio de Janeiro, Rio de Janeiro. 1989.

HECKMAN, C. W.; HARDOIM, E. L.; FERREIRA, S. P.; KRETZEHMAR, A. U. Preliminary observations on some cosmopolitan algae in ephemerae water bodies of the Pantanal, Mato Grosso, Brazil. In: GOPAL, B.; HILLBRICHT- ILKOWSKA, A.; WETZEL, R. G. (Ed.). Wetlands and ecotones: studies on landwater interations. New Delhi: International Scientific Publications, 1993. p. 279-292.

HUSZAR, V. L. M. Floristic composition and biogeographical aspects of phytoplankton of an Amazonian floodplain lake (Lago Batata, Pará, Brasil). Acta Limnologica Brasiliensia, Botucatu, v. 8, n. 1, p. 127-136, 1996.

HUSZAR, V. L. M.; REYNOLDS, C. S. Phytoplankton periodicity and sequences of dominance in an Amazonian flood-plain lake (Lago Batata, Pará, Brazil): responses to gradual environmental change. Hydrobiologia, Brussels, v. 346, n. 1-3, p. 169-181, 1997. HUSZAR, V. L. M.; SILVA, L. H. S.; DOMINGOS, P.; MARINHO, M.; MELO, S. Phytoplankton species composition in more sensitive than OECD criteria to the trophic status of three Brazilian tropical lakes. Hydrobiologia, Brussels, v. 369/370, n. 0, p. 59-71, 1998.

JUNK, W. J.; BAILEY, P. B.; SPARKS, R. E. The flood pulse concept in river-floodplain systems. In: DODGE, DP. (Ed.). Proceedings of the International Large River Symposium. Honey Arbor: Canadian Special Publication of Fisheries and Aquatic Sciences, 1989. p. 110-117.

JUNK, W. J.; CUNHA, C. N.; WANTZEN, K. M.; PETERMANN, P.; STRUSSMANN, C.; MARQUES, M. I.; ADIS, J. Biodiversity and its conservation in the Pantanal of Mato Grosso, Brazil. Aquatic Sciences, Bremen, v. 68, p. 278-309, 2006.

LIMA, D. Estrutura das comunidades zooplanctônicas e fitoplanctônicas do Lago Recreio - Pantanal de Barão de Melgaço-MT. 1996. 209 f. Dissertação (Mestrado em Ecologia) Universidade Federal de São Carlos, São Carlos. 1996.

LOBO, E.; LEIGHTON, G. Estruturas comunitárias de las fitocenosis planctónicas de los sistemas de desenbocaduras de rios y esteros de la zona central de Chile. Revista de Biología Marina y Oceanografía, Valparaiso, v. 22, n.1, p. 1-29, 1986.

LOVERDE-OLIVEIRA, S. M. Variáveis limnológicas e análise temporal da comunidade fitoplanctônica da Baía Sá Mariana, Pantanal Barão de Melgaço - MT. 1999. 84 f. Dissertação (Mestrado em Ecologia e Conservação da Biodiversidade) Universidade Federal de Mato Grosso, Cuiabá. 1999.

LOVERDE-OLIVEIRA, S. M. Implicações da complexidade hidrológica sobre os padrões Limnológicos na Lagoa do Coqueiro, Pantanal de Mato Grosso: alternância de estados estáveis. 2005. 104 f. Tese (Doutorado em Ecologia) - Universidade Federal do Rio de Janeiro, Rio de Janeiro. 2005.

LOVERDE-OLIVEIRA, S. M.; ADLER, M.; SILVA. V. P. Phytoplankton, periphyton and metaphyton of the Pantanal floodplains: species composition and richness, density, biomass and primary production. In: JUNK, W. S.; CUNHA, C.; WANTZEN, K. (Org.). The Pantanal ecology, biodiversity and sustainable management of a large neotropical seasonal wetland. Sofia: Pensoft Publishers, 2011. p. 235-256.

LOVERDE-OLIVEIRA, S. M.; FIGUEIREDO, D. M. Caracterização das comunidades de fitoplâncton e zooplâncton. In: FIGUEIREDO, D. M.; SALOMÃO, F. X. T. (Ed.). Rio Cuiabá uma abordagem socioambiental. Cuiabá: Entrelinhas, Ed. UFMT, 2009. p. 95-101.

LOVERDE-OLIVEIRA, S. M.; HUSZAR, V. L. M. Phytoplankton ecological responses to the flood pulse in a Pantanal lake, Central Brazil. Acta Limnologica Brasiliensia, Botucatu, v. 19, n. 2, p. 117-130, 2007.

LOVERDE-OLIVEIRA, S. M; HUSZAR, V. L. M; FANTINCRUZ, I. Implications of the flood pulse on morphometry of a Pantanal lake (Mato Grosso state, Central Brazil). Acta Limnologica Brasiliensia, Botucatu, v. 19, n. 4, p. 453-461, 2007. LOVERDE-OLIVEIRA, S. M.; HUSZAR, V. L. M.; MAZZEO, N.; SCHEFFER, M. Hydrology - driven regime shifts in a shallow tropical lake. Ecosystems, New York, v. 12, p. 807-819, 2009.

LOVERDE-OLIVEIRA, S. M.; PIETRO-SOUZA, W.; CARDOSO, S. J.; FANTIN-CRUZ, I.; MATEUS, L. M. Fatores associados à distribuição espacial do fitoplâncton em lagos de inundação (Pantanal Norte, Brasil). Oecologia Australis, Rio de Janeiro, v. 16, n. 4, p. 770-781, 2012. 
MARÇAL, S. F. Variação espacial e sazonal da abundância relativa do fitoplâncton na baía do Coqueiro (Pantanal de Poconé, Mato Grosso, Brasil). 2005. 53 f. Dissertação (Mestrado em Ecologia) - Universidade Federal de Mato Grosso, Cuiabá. 2005.

MARGALEF, R. Limnologia. Barcelona: Ediciones Omega, $1983.1010 \mathrm{p}$.

MOREIRA-FILHO, H.; VALENTE-MOREIRA, I. M. Avaliação taxonômica e ecológica das diatomáceas (Bacillaryophyceae) epífitas em algas pluricelulares obtidas nos litorais dos estados do Paraná, Santa Catarina e São Paulo. Boletim do Museu Botânico Municipal, Curitiba, v. 47, p. 1, p. 1-7, 1981.

MOURA, A. T. N. Estrutura e dinâmica da comunidade fitoplanctônica numa lagoa eutrófica, São Paulo, SP, Brasil, a curtos intervalos de tempo: comparação entre épocas de chuva e seca. 1997.172 f. Dissertação (Mestrado em Biologia Vegetal) Universidade Estadual Paulista, Rio Claro. 1997.

NABOUT, J. C.; NOGUEIRA, I. S. Spatial and temporal dynamics of phytoplankton functional group in a blocked valley (Brazil). Acta Limnologica Brasiliensia, Botucatu, v. 19, n. 3, p. 305-314, 2007.

NASCIMENTO, E. C. Variação espaço-temporal da comunidade fitoplanctônica em um reservatório eutrófico do semi-árido do Nordeste (Pernambuco - Brasil). 2010. 91 f. Dissertação (Mestrado em Botânica) - Universidade Federal Rural de Pernambuco, Recife. 2010.

NOGUEIRA, F. M. B. Importância das macrófitas aquáticas Eichhornia azurea Kunth. e Scirpus cubensis Poepp \& Kunth. na ciclagem de nutrientes e nas principais características limnológicas da Lagoa Infernão (SP). 1989. 147 f. Dissertação (Mestrado em Ecologia e Recursos Naturais) - Universidade Federal de São Carlos, São Carlos. 1989.

OLIVEIRA, M. D.; CALHEIROS, D. F. Flood pulse influence on phytoplankton communities of the south Pantanal floodplain, Brazil. Hydrobiologia, Brussels, v. 427, n. 1, p. 101-112, 2000.

PAYNE, A. The ecology of tropical lakes and rivers. Chichester: John Wiley e Sons, 1986. 301 p.

REYNOLDS, C. S. The ecology of freshwater phytoplankton. Cambridge: Cambridge University Press, 1984. 384 p.
RODRIGUES, L.; PEREIRA, S. R. S.; BONECKER, C. C. Composition and abundance of the periphytic meiofauna in lentic systems of the upper Paraná River floodplain. In: AGOSTINHO, A. A.; RODRIGUES, L.; GOMES, L. C.; THOMAZ, S. M.; MIRANDA, L. E. (Org.). Structure and functioning of the Paraná River and its floodplain. Maringá: EDUEM, 2001. p. 5155.

RODRIGUES, L. C. ; TRAIN, S. ; ROBERTO, M. C. ; PAGIORO, T. Seasonal fluctuation of some limnological variables on a floodplain lake (Patos Lagoon) of the upper Paraná River, Mato Grosso do Sul State, Brazil. Brazilian Archives of Biology and Technology, Curitiba, v. 45, n. 4, p. 499-513, 2002.

SILVA, E. L. V.; OLIVEIRA, M. D.; ISHII, I. H. Estrutura da comunidade fitoplanctônica do rio Paraguai e canal do Tamengo. In: SIMPÓSIO SOBRE RECURSOS NATURAIS E SÓCIOECONÔMICOS DO PANTANAL, III, 2000, Corumbá. Anais... Corumbá: EMBRAPA Pantanal, 2000. p. 1-22.

SIMONSEN, R. The diatom system: ideas on phylogeny. Bacillaria, London, v. 2, p. 9-71, 1979.

TRAIN, S.; RODRIGUES, L. C. Temporal fluctutations of the phytoplankton community of the Baía River, in the upper Paraná River floodplain, Mato Grosso do Sul, Brazil. Hydrobiologia, Belgium, v. 361, n. 1-3, p. 125-134, 1998.

TRAIN, S.; RODRIGUES, L. C.; BORGES, P. F.; UYEDA, A. T.; MITIKONACAGAVA, M.; BOVO, E. M. Fitoplâncton. 2001. Disponível em: <http://www.peld.uem.br/Relat2001/pdf/ componente_bioticos_fitoplancton.pdf $>$. Acesso em: 3 jun. 2009.

TREMARIN, P.; LOVERDE-OLIVEIRA, S.; LUDWIG, T. V.; TORGAN, L. C. Ultrastructure and distribution of Aulacoseira gessneri. Diatom Research, London, v. 26, n. 2, 189-197, 2011.

VAN DEN HOEK, C.; MANN, D. G.; JAHNS, H. M. Algae: an introduction to Phycology. Cambridge: Cambridge University Press, 1997. $627 \mathrm{p}$.

ZALOCAR DE DOMITROVIC, Y. Structure and variation of the Paraguay river phytoplankton in two periods of its hydrological cycle. Hydrobiologia, Brussels, v. 472, n. 1-3, p. 177-196, 2002.

ZALOCAR DE DOMITROVIC, Y. Effect of flutuations in water level phytoplankton in three lakes of Paraná river floodplain (Argentina). Hydrobiologia, Brussels, v. 510, n. 1-3, p.175-193, 2003. 
APPENDIX 1: List of species of phytoplankton flora of the Coqueiro Lake

\section{Cyanophyceae}

Anabaena circinalis Ranhorst ex. Bornet \& Flahault

Anabaena flos aquae Lyngberg Brébissonii

Anabaena planctonica Brunnthaler

Anabaena variabilis Kutzing

Aphanocapsa incerta (Lemmermann) Cronberg \& Komarek

Aphanocapsa holsatica (Lemmermann) Cronberg \&

Komarek

Aphanocapsa minutissima (W. West) Komarkova-

Legrenova \& Cronberg

Aphanocapsa planctonica (G. M. Smith) Komárek \&

Anagnostidis

Aphanothece smithii Komarekova-Legrenova \& Cronberg

Calothrix sp.

Coelosphaerium sp.

Chroococcus sp.

Cyanosarcina sp.

Geitlerinema amphybium Gommot

Gloeocapsa sp.

Merismopedia tenuissima (W. West) Komarkova-Legrenova

\& Cronberg

Microcystis cf. ichthyoblabe Kutzing

Oscillatoria annea Van Gorr

Oscillatoria articulata Gardner

Oscillatoria granulata (Gardner)

Oscillatoria ornata (Kutzing) Gomont

Oscillatoria sancta (Kutzing) Gomont

Oscillatoria tenuis (C. Agardh) Gomont

Phormidium sp.

Planktolyngbia cf. circuncreta (G. S. West) Anagnostidis \&

Komarkova

Pseudoanabaena limnetica Lemmermann

Rabdoglea sp.

Raphydiopsis sp.

Spirulinoideae

Stigonematales

Synechococcus sp.

Synechocystis aquatilis Sauvageu

Trichodesmium iwanoffianum Nygaard

\section{Chrysophyceae}

Dinobryon sertularia Ehrenberg

Mallomonas sp.

Synura sp.

Xanthophyceae

Centritractus sp.

Isthmochloron lobulatum Nageli

Ophiocytium sp.

Pseudostaurastrum sp.

Tetraedriella $\mathrm{sp}$.
Tetraplektron torsum (Skuja) Dedusenko Scegoleva

\section{Bacillariophyceae}

Actnella sp.

Asterionella sp.

Aulacoseira ambigua (Grunow) Krammer

Aulacoseira distans (Ehrenberg) Simonsen

Aulacoseira granulata (Ehernberg) Simonsen.var.

angustissima

Aulacoseira granulata (Ehernberg) Simonsen.var.

granulata

Aulacoseira italica (Eherberg) Simonsen

Aulacoseira pseudogranulata (A. Cleve-Euler)

Cyclotella sp.

Cymbella sp.

Entomoneis sp.

Eunotia camelus Ehrenberg

Eunotia flexuosa Brébisson

Eunotia formica Ehrenberg

Eunotia monodon Ehrenberg

Eunotia sudetica (O.F. Müller)

Fragilaria virescens Ralfs

Gomphonema sp.

Navicula cuspidata (Kutzing) Kutzing

Nitzschia sp.

Pinnularia sp.

Surirella bisseriata Brébisson

Surirella robusta Ehrenberg

Surirella sp.

Urosolenia sp.

Cryptophyceae

Cryptomonas ovata Ehrenberg

Dinophyceae

Peridinium cf. umbonatum Stein

Euglenophyceae

Euglena acus Ehrenberg

Euglena fusca (Klebs) Lemmermann

Euglena oxyurus Schmarda

Euglena spiroides Lemmermann

Euglena spirogyra Ehrenberg

Lepocinclis caudata Da Cunha

Lepocinclis ovum (Ehrenberg) Lemmermann

Lepocinclis piriformis Da Cunha

Lepocinclis salina Da Cunha

Lepocinclis tubiniformis De flandre

Phacus caudatus Hubner

Phacus contortus Bourrelly

Phacus helicoides Pochmann

Phacus longicauda (Ehrenberg) Dujardin

Phacus onys Pochmann 
Phacus orbiculares Hubner

Phacus suecicus Lemmermann

Phacus tortus (Lemmermann) Skv

Phacus undulatus (Skvortzov) Pochmam

Strombomonas cf. argentinensis G. de Emiliani

Strombomonas maxima (Skv.) Deflandre

Strombomonas ovalis (Playfir) Deflandre

Trachelomonas abrupta (Swirenko) Deflandre

Trachelomonas armata (Ehrenberg) Stein

Trachelomonas dastuguei Balech

Trachelomonas dubia (Swirenko) Deflandre

Trachelomonas hirta Da Cunha

Trachelomonas megalacantha Da Cunha

Trachelomonas raciborskii (Woloszynska) Conrad

Trachelomonas robusta (Swirenko) Deflandre

Trachelomonas rugulosa (Stein) Deflandre

Trachelomonas similis Stokes

Trachelomonas verrucosa Stokes

Trachelomonas volvocina Ehrenberg

Trachelomonas volvocinopsis Swirenko

\section{Chlorophyceae}

Actinastrum aciculare Playfir

Actinastrum hantzschii Lagerheim

Ankistrodesmus bibraianus (Reinsch) Korsikov

Actinastrum falcatus (Corda) Ralfs

Actinastrum fusiformis Corda

Actinastrum gracilis (Reinsch) Korsikov

Botryococcus braunii Kutzing

Chaetosphaeridium sp.

Chlamydomonas sp.

Coelastrum indicum Turner

Coelastrum proboscideum Bohlin

Coelastrum pulchrum Shimidle

Coelastrum pulchrum var. colfer (Kammerer) Kom.

Coelastrum reticulatum (Dangeard) Senn

Coenocystis subcylindrica Korsikov

Crucigenia fenestrata (Schmidle) Schmidle

Crucigenia quadrata Morren

Crucigeniella crucifera (Wolle) Komárek

Crucigeniella saguei Komárek

Dictyosphaerium ehrenbergianum Nageli

Dictyosphaerium elegans Nageli

Dictyosphaerium pulchellum Wood

Dimorphococcus sp.

Eudorina sp.

Eutetramorus fottii Hindák

Golenkinia sp.

Hydrodictyon sp.

Kirchneriella contorta Schmidle

Kirchneriella dianae (Bohling) Comas

Kirchneriella lunaris (Kirchner) Moebius
Monoraphidium caribeum Hindák

Monoraphidium contortum (Turner) Komarkova-Legnerova

Monoraphidium minutum (Nageli) Komarkova-Legnerova

Monoraphidium tortile (W. \& G. S. West) Komarkova-

Legnerova

Oocystis lacustris Chodat

Pachycladella sp.

Pandorina morum (O. F. Muller) Bory

Pediastrum argentiniense Bourr \& Tell

Pediastrum duplex Meyen

Pediastrum tetras (Ehrenberg) Ralfs

Pleudorina sp.

Radiococcus bavaricus (Skuja) Komm.

Radiococcus nimbatus (De-Wildem) Schmidle

Scenedesmus acutus Meyen

Scenedesmus acuminatus (Lagerh) Chodat

Scenedesmus alternans Reinsch

Scenedesmus ecornis (Ehrenberg) Chodat

Scenedesmus ellipticus (W. \& G. S. West) Chodat

Scenedesmus intermedius Chodat var. intermedius

Scenedesmus perforatus Lemmermann

Schroederia sp.

Selenastrum sp.

Sorastrum sp.

Tetraedron sp.

Tetrastrum punctatum (Schmidle) Ahlstrom \& Tiffany

Treubaria sp.

Trochiscia sp.

Ulothrix variabilis Kutzing

Oedogoniophyceae

Bulbochaete sp.

Oedogonium sp.

Zygnemaphyceae

Actinotaenium wollei (Nageli) Teiling

Bambusina borreri Ralfs (Cleve)

Closterium aciculare West

Closterium acutum (Brébisson) Ralfs

Closterium correctum Meneghini

Closterium gracile Brébisson

Closterium lineatum Ehrenberg

Closterium regulare Brébisson

Closterium setaceum (Ehrenberg) Ralfs

Cosmarium commissurale Brébisson

Cosmarium denticulatum Borge

Cosmarium lagoense (Nordstedt) Nordstedt

Cosmarium obsoletum (Hantzsch) Reinsch

Cosmarium paraguayense Borge

Cosmarium pseudopyramidatum Lundell

Cosmarium quadrum Borge

Cosmarium redimitum Borge

Cosmarium subspeciosum Borge 
Desmidium cylindricum Greville

Desmidium grevillii (Kutzing) De Bary

Euastrum ansatum Ehrenberg

Euastrum divergens Joshua

Euastrum dubium Nageli

Euastrum evolutum (Nordstedt) West \& West

Euastrum gemmatum (Brébisson) Ralfs

Euastrum obesum Joshua

Euastrum subintegrum Nordestedt

Gonatozygon aculeatum Hastings

Gonatozygon monotaenium De Bary

Gonatozygon pilosum Wolle

Haplotaenium ehrenbeergii (Brébisson) De Bary

Haplotaenium minutum (Ralfs) Delponte

Haplotaenium nodosum (Bailey) Lundell

Haplotaenium tridentulum (Wolle) West \& West

Haplotaenium trabecula (Ehrenberg) Nageli

Hyalotheca dissiliens (Smith) Brébisson

Hyalotheca dubia Kutzing

Hyalotheca indica Turner

Micrasterias abrupta (W. e G.S. West)

Micrasterias borgei Krieger

Micrasterias foleacea Bailey

Micrasterias furcata Ralfs

Micrasterias laticeps Nordstedt

Micrasterias mahabuleshwarensis Hobsen

Micrasterias radiata Hassal

Micrasterias radiosa Ralfs

Micrasterias toreyi Bailey

Micrasterias tropica Nordstedt

Mougeotia sp.

Netrium sp.

Onychonema laeve Nordsted var latum West \& West

Penium sp.

Phymatodocis sp.

Spirogyra sp.

Spondylosium panduriforme (W. \& G. S. West) Teiling
Spondylosium pulchellum Archer

Spondylosium pulchrum (Bailey) Archer

Staurastrum cf. bidentulum Nordstedt

Staurastrum boergesenii Raciborski

Staurastrum brasiliensis Nordstedt

Staurastrum leptocanthum Nordstedt

Staurastrum leptocladum Nordstedt

Staurastrum margaritaceum (Ehrenberg) Meneghini

Staurastrum minnesotense Wolle

Staurastrum nudibrachiatum Borge

Staurastrum pinnatum Turner

Staurastrum quadrangulare Brébisson

Staurastrum rotula Nordstedt

Staurastrum sebaldi Reinsch

Staurastrum setigerum Cleve

Staurastrum sexangulare (Bulnheim) Rabenhorst

Staurastrum tetracerum Ralfs

Staurastrum trifidum Nordstedt

Staurodesmus clepsydra (Nordstedt) Teiling

Staurodesmus convergens (Ehrenberg) Teiling

Staurodesmus cornutus (Wolle) Teiling

Staurodesmus dejectus (Brébisson) Teling

Staurodesmus lobatus Borgesen

Staurodesmus mamillatus (Nordestedt) Teiling

Staurodesmus maximus Borge

Staurodesmus megacanthus (Lundell) Thummark

Staurodesmus subulatus (Kutzing) Croasdale

Staurodesmus triangularis (Lagerheim)

Staurodesmus validus (W. \& G.S. West) Thomasson

Teilingia wallichi (Jac.) Bou var. anglica (W. \& W.) Foster

Triploceras gracile Bailey

Xanthidium amazonense Scott \& Croasdale

Xanthidium canadense Joshua

Xanthidium cristatum Brébisson

Xanthidium mamillosum Gronblad

Xanthidium sexangulare Gronblad

Xanthidium trilobum Nordstedt 
APPENDIX2: A-Bacillariohyceae(1A)Aulacoseira ambigua, (2A)Aulacoseira granulata var. granulata; B-Cyanophyceae(1B) Microcystis ichthyoblabe, (2B) Planktolyngbia cf. circuncreta, (3B) Anabaena planctônica; C - Euglenophyceae (1C) Trachelomonas volvocina, (2C) Trachelomonas cf. volvocinopsis; D - Chlorophyceae (1D) Botryococcus braunii, (2D) Coelastrum indicum, (3D) Coelastrrum pulchrum, (4D) Crucigeniella crucifera, (5D) Eudorina sp.

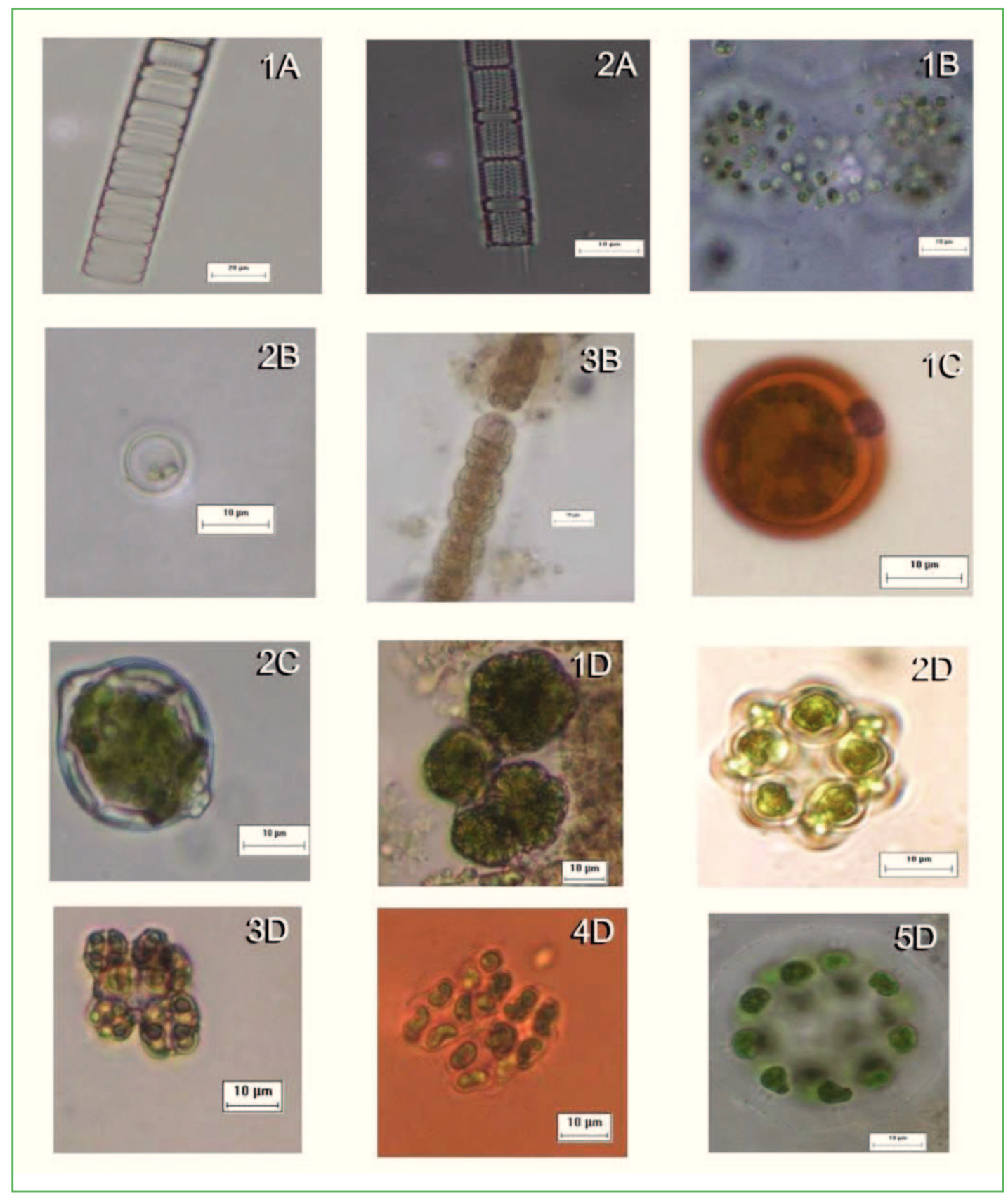

